\title{
POSTURAL PROFILE OF CLASSICAL BALLERINAS FROM THE VALE DO SÃO FRANCISCO REGION OF BRAZIL
}

\author{
PERFIL POSTURAL DAS BAILARINAS CLÁSSICAS DO VALE DO SÃO FRANCISCO \\ PERFIL POSTURAL DE BAILARINAS CLÁSICAS DEL VALLE DEL SÃO FRANCISCO
}

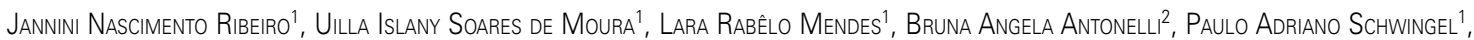
Rita di Cássia de Oliveira Angelo ${ }^{1}$

1. Universidade de Pernambuco, UPE, Campus Petrolina, Pernambuco, Brazil.

2. Faculdade São Francisco de Juazeiro (FASJ), Juazeiro - BA, Brazil.

\begin{abstract}
Objective: The study aimed to determine the association between postural changes and practice of classical ballet among ballerinas from Integrated Administrative Region of Development (RIDE) in Polo Petrolina/PE and Juazeiro/BA. Methods: Cross-sectional observational study with 19 classical ballerinas aged over 15 years and at least 5 years of uninterrupted classical ballet practice. The anthropometric assessment included measurements of total body mass, height and body mass index (BMI). Postural evaluation was performed using the photogrammetric method with help of Posturograma ${ }^{\circledR}$ and SAPO ${ }^{\odot}$ software. Results: The mean age was $25.3 \pm 11.7$ years and the mean BMI was $21.4 \pm 2.9 \mathrm{~kg} / \mathrm{m}^{2}$. Approximately $74 \%$ of classical ballerinas had normal anthropometric profile. The postural profile of the classical ballerinas showed inclination and protrusion of the head, trunk rotation, rectification of cervical lordosis, increased thoracic kyphosis, increased lumbar lordosis, pelvic inclination and anteversion. Conclusion: The practice of ballet led to changes in body alignment of the classical ballerinas evaluated. The results points out to the need of postural re-education in order to contribute for the kinetic-functional balance of classical ballet practitioners.
\end{abstract}

Keywords: Dancing; Posture; Photogrammetry; Spine; Body Mass Index.

\section{RESUMO}

Objetivo: O estudo teve como objetivo verificar a associação entre alterações posturais e a prática do balé clássico em bailarinas da Região Administrativa Integrada de Desenvolvimento (RIDE) do Polo Petrolina/PE e Juazeiro/BA. Métodos: Estudo observacional de corte transversal com 19 bailarinas com idade superior a 15 anos e, no mínimo, 5 anos ininterruptos de prática de balé clássico. A avaliação antropométrica consistiu na aferição da massa corporal total, na mensuração da estatura e no cálculo do índice de massa corporal (IMC). A avaliação postural ocorreu através do método fotogramétrico por meio dos software Posturograma ${ }^{\circledR}$ e $S A P O^{\circ}$. Resultados: A média de idade foi 25,3 $\pm 11,7$ anos e a média do IMC foi 21,4 \pm 2,9 kg/m2. Aproximadamente $74 \%$ das bailarinas clássicas apresentaram perfil antropométrico normal. O padrão postural das bailarinas mostrou inclinação e protrusão da cabeça, rotação do tronco, retificação da lordose cervical, aumento da cifose torácica, aumento da lordose lombar, inclinação e anteversão pélvica. Conclusão: A prática do balé levou a alterações no alinhamento corporal das bailarinas avaliadas. Os resultados sinalizam para a necessidade de reeducação postural, de modo a contribuir com o equilíbrio cinético-funcional de praticantes de balé clássico.

Descritores: Dança; Postura; Fotogrametria; Coluna Vertebral; Índice de Massa Corporal.

\section{RESUMEN}

Objetivo: El objetivo del estudio fue determinar la asociación entre los cambios posturales y la práctica de bailarinas del ballet clásico de la Región Administrativa Integrada de Desarrollo (RIDE) en Polo Petrolina/PE y Juazeiro/BA. Métodos: Estudio transversal observacional con 19 bailarinas clásicas mayores de 15 años y al menos 5 años de práctica de ballet clásico ininterrumpida. La evaluación antropométrica incluyó medición de índice de masa de masa corporal total, de la altura y el cálculo del índice de masa corporal (IMC). La evaluación postural se realizó mediante el método fotogramétrico y los software Posturograma ${ }^{\circledR}$ y SAPO ${ }^{\odot}$. Resultados: La edad media fue de 25,3 $\pm 11,7$ años y la media del IMC fue de $21,4 \pm 2,9 \mathrm{~kg} / \mathrm{m}^{2}$. Aproximadamente el $74 \%$ de las bailarinas clásicas tenía perfil antropométrico normal. El perfil postural estándar de las bailarinas clásicas mostró inclinación y protrusión de la cabeza, la rotación del tronco, corrección de la lordosis cenvical, aumento de cifosis torácica, aumento de la lordosis lumbar, inclinación y anteversión de la pelvis. Conclusión: La práctica del ballet llevó a cambios en la alineación del cuerpo de las bailarinas clásicas evaluadas. Los resultados señalan la necesidad de re-educación postural para contribuir al equilibrio cinético-funcional de las bailarinas clásicas.

Descriptores: Baile; Postura; Fotogrametría; Columna Vertebral; Índice de Masa Corporal.

\section{INTRODUCTION}

The practice of ballet requires an artistic routine of specific physical aptitudes, with a high level of muscular strength, flexibility, joint mobility, balance, and adequate body composition. ${ }^{1}$ In order to develop a dance with perfection, the musculoskeletal system is submitted to extreme demands that significantly affect the motor behavior of dan- 
cers and favor the establishment of improper postural standards., ${ }^{2,3}$

In this context, let us use the example of the execution of the turnout, a position used in most performance steps that requires the lateral rotation of both hips of between $55^{\circ}$ and $70^{\circ}$, with the knees in extension and the heels together. Any condition that limits this range of motion forces the ballerina to effect pelvic retroversion, increased lumbar lordosis, and subtalar pronation in compensation. 3,4

Excessive work of the lumbar spine causes constant activation of the paravertebral muscles, whether in the compensations made to perform the turnout or in the jumps that impose hyperextension on the spine. Paravertebral hyperactivity can culminate in muscular imbalance in relation to the muscles of the abdominal wall. This imbalance is cited as the possible cause of pain and spasms in the lumbar region. ${ }^{5,6}$

Current studies have found differences between the gait patterns of classical ballerinas and non-ballerinas and have shown that the intensive practice of ballet long term affects the kinematic pattern of certain joints while walking. The results of these studies have demonstrated increased pressure on the forefoot during the support phase, increased extension, and lateral rotation of the hips, pelvic anteversion and obliquity, as well as overload in the lumbosacral region. ${ }^{3,7}$

To maintain good posture, the corporal segments must be aligned to minimize muscular torque and tension throughout the whole kinetic chain. In order to be classified as abnormal, the alignment must produce functional limitations that can occur in any location in the kinetic chain, in the adjacent or distal joints by means of compensatory movements or postures. ${ }^{8}$

In terms of the postural misalignments specific to classical dancers reported in the literature, there is no conclusive postural standard. There are discrepancies in the findings, the most commonly described being protrusion of the head, ${ }^{8}$ rectification of the lumbar and thoracic curvatures, ${ }^{9,10}$ lumbar hyperlordosis, ${ }^{11}$ anteversion, ${ }^{12}$ and pelvic retroversion. ${ }^{9,10}$ Whether maintained statically or executed repetitively, abnormal postural alignment can be an important precipitator of soft tissue pain. ${ }^{13}$

Given the above, it is possible to construct the hypothesis that classical ballet training routines change the alignment of the corporal segments of those who perform them. Furthermore, no description of a specific postural norm for the classical ballerina was confirmed in the literature. Within this context, the objective of this study was to confirm the possible association between postural changes and the practice of classical ballet in ballerinas of the Integrated Development Region (RIDE) of the Petrolina/PE and Juazeiro/BA pole.

\section{METHODS}

This was an analytical, descriptive, cross-sectional study, developed and conducted at the Human Performance Research Laboratory of the UPE Campus Petrolina. It was conducted in compliance with resolution no. 466, of 12 December 2012 of the National Health Council and approved by the Institutional Review Board of Universidade de Pernambuco (CEP-UPE), Recife, PE, Brazil (CAAE 15930113.3.0000.5207).

Initially, the six main dance schools of the RIDE of the Petrolina/ $\mathrm{PE}$ and Juazeiro/BA pole were contacted via an invitation to all the ballerinas of each establishment. Among those that showed interest in participating in the study, 19 satisfied the eligibility requirements adopted and were evaluated in terms of corporal alignment. The criteria adopted for this study were being older than 15 years of age, having a minimum of five consecutive years of classical ballet practice, having no diagnosis of orthopedic and/or rheumatological pathologies, scolioses, spina bifida, and/or osteomuscular injuries that would make evaluation impossible.

All the participants agreed to participate freely in the study by signing the informed consent form if 18 years or older or if minors, by the signature of their legal guardians. During follow-up, the sample group remained intact.
The evaluation of posture was conducted in a reserved environment using a photogrammetric method. The preparatory procedures for acquiring images, marking the anatomical points, and tracing the referential lines were performed by a single, previously trained examiner who followed the method described in the reliability manual of the Posturograma ${ }^{\circledR}$ (FISIOMETER, Rio de Janeiro, RJ, Brazil, Release $3.0,2006)$ software, ${ }^{14}$ a method used to measure the distances between the points of reference and between the points and the ground (Figure 1). SAPO ${ }^{\odot}$ (Software para Avaliação Postural [Software for Postural Evaluation], São Paulo, SP, Brazil, version 0.68, 2007) was used to measure the angles (Figure 2)..$^{15}$

A semi-professional Cybershot DSC-HX1 (Sony Corp. Tokyo, Japan) 9.1 megapixels digital camera was used for the photographic records, focused at the level of the umbilical scar. The camera was mounted on a tripod one meter above the ground and three meters from the symmetrograph. The images were captured in the frontal and sagittal planes. The volunteers were placed in a standing position in front of the symmetrograph with their feet positioned so that the medial malleoli remained in the direction of the sagittal plane. ${ }^{14}$

Bone palpation of the anatomical references for the computerized measuring followed the method proposed in the specialized literature. ${ }^{16}$ The anatomical landmarks, such as the glabella $(G)$, the chin (C), and the upper margin of the manubrium of sternum (MS) guided the drawing of the plumb line (PL). The others, such as the temporomandibular joint interline (TMJI), the acromioclavicular joints (AC), the anterior superior iliac spine (ASIS), the posterior superior iliac spine (PSIS), the anterior tibial tuberosity (ATT), the lateral malleolus $(\mathrm{LM})$, and the medial malleolus (MM) were bilaterally marked and applied in the measurement of the distances.

In the sagittal plane, the measurement of the angles was performed using SAPO ${ }^{\odot} .^{17}$ The anatomical markers, such as the occipital protuberance (OP), the tragus of the ear (TE), and the spinous process (SP) were used in measuring the angle of protrusion of the head (PH). The angle of cervical lordosis $(\mathrm{CL})$ was confirmed using the OP and the spinous processes of C4 and C7. Thoracic kyphosis (TK) was measured using the spinous processes of $\mathrm{C} 7, \mathrm{~T} 7$, and $\mathrm{T} 12$, and lumbar lordosis (LL) measured by means of the spinous processes of T12, L3, and L5. The pelvic tilt angle was also measured using the ASIS and PSIS bilaterally.

The evaluation of the anthropometric profile of the ballerinas consisted of measuring the total body mass $(\mathrm{Kg})$ and height $(\mathrm{m})$ using a W200/5 digital scale (Welmy Indústria e Comércio Ltda., Santa Bárbara d'Oeste, SP, Brazil). The body mass index (BMI) was calculated by dividing the total body mass by the height squared $\left(\mathrm{BMl}=\mathrm{kg} / \mathrm{m}^{2}\right) .{ }^{18}$
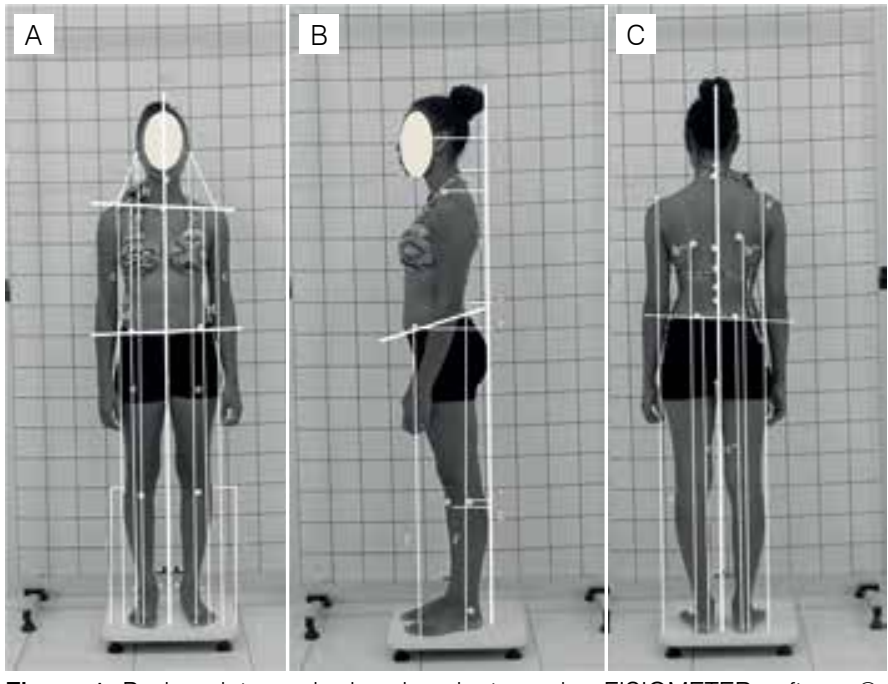

Figure 1. Body points marked and evaluates using FISIOMETER software ${ }^{\circledR}$, in anterior (A), profile $(B)$, and posterior $(C)$ views. 


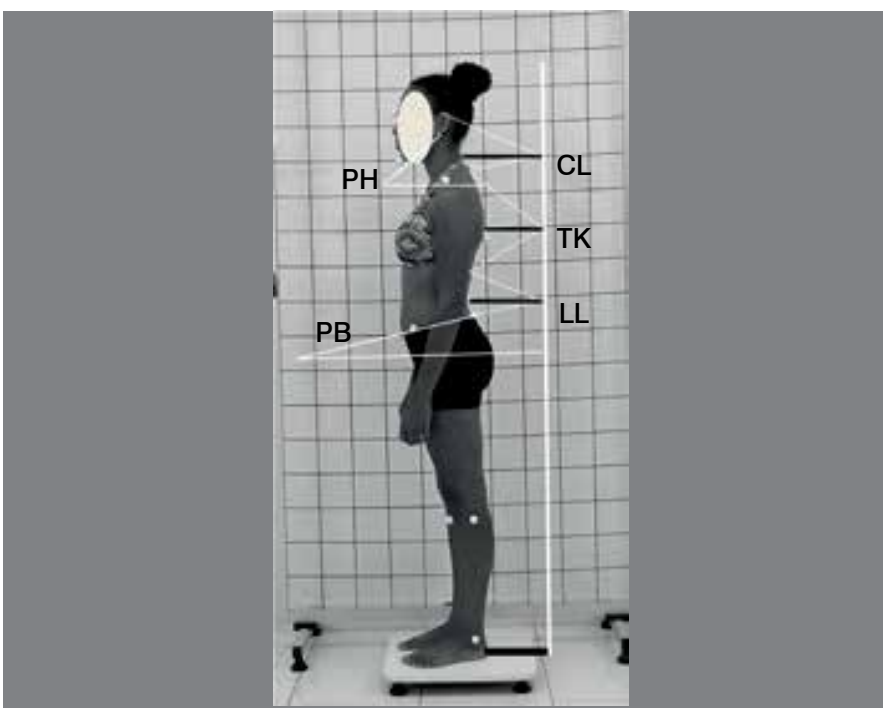

Figure 2. Evaluation of body angles using SAPO ${ }^{\circ}$.

For the ballerinas between the ages of 15 and 20, the classification and cutoffs recommended by the World Health Organization (WHO) for this age group were used. ${ }^{19}$ For those above the age of 20 , the classification recommended by the WHO for adults was used. ${ }^{20}$

The descriptive statistical analysis was performed using the Statistical Package for the Social Sciences (SPSS Inc., Chicago, IL, USA, Release 16.0.2, 2008). After confirming the homoscedasticity (Bartlett's test) and the normality of the data (Shapiro-Wilk test), continuous variables were presented as means \pm standard deviation, while categorical data were presented as absolute and relative frequencies. Possible associations were verified using the Pearson chi-squared or Fisher's exact test. Comparisons between groups were conducted using the $t$ test for independent samples, while comparisons of laterality were established with the paired $t$ test. All the tests were two-tailed and all analyses adopted a significance level of $5 \%$ and confidence intervals $(\mathrm{Cl})$ when determined to be exact.

\section{RESULTS}

The average age of the dancers evaluated was $25.3 \pm 11.7$ years, with half of the sample $(n=10,52.6 \%)$ in the age group ranging from 15 to 20 years of age. The average time practicing ballet was $12.5 \pm 8.4$ years. In terms of the pattern of dominance, all the ballerinas were right dominant.

The anthropometric data confirmed were average total body mass and average height with values equal to $54.1 \pm 8.1 \mathrm{~kg}$ and $1.59 \pm 0.06$ $\mathrm{m}$, respectively. The average BMl was $21.4 \pm 2.9 \mathrm{~kg} / \mathrm{m}^{2}$, with most of the sample classified as being of normal weight $(n=14,73.7 \%), 15.8 \%$ $(n=3)$ as underweight, and $10.5 \%(n=2)$ as overweight.

In terms of laterality, in the photogrammetric evaluation we observed asymmetry of the head, shoulders, and pelvis in the frontal plane, demonstrated by the significant difference between the TMJ-G, AC-G, ASIS-G, and HF-S, confirming greater values on the left, suggesting the inclination of the head and pelvis to the right and the elevation of the left shoulder. In the sagittal plane, the measurements of the distances in reference to the PL had significantly greater values on the left side, which could indicate a tendency for rotation of the trunk to the right. In the posterior view, there was no difference between the measurements in terms of laterality (Table 1).

Results obtained from the FISIOMETER ${ }^{\circledR}$ software. TMJ-AC: Distance in $\mathrm{cm}$ from the temporomandibular joint to the acromioclavicular joint. TMJ-G: Distance in $\mathrm{m}$ from the temporomandibular joint to the ground. AC-G: Distance in $\mathrm{m}$ from the acromioclavicular joint to the ground. ASIS-AC: Distance in $\mathrm{cm}$ from the anterior superior iliac spine to the acromioclavicular joint. ASIS-G: distance in $m$ from the anterior superior iliac spine to the ground. HF-G: Distance from the head of the fibula to the ground. PL-TMJ: Distance in $\mathrm{cm}$ from the posterior line to the temporomandibular joint. PL-CS: Distance in $\mathrm{cm}$ from the posterior line to vertebra C4. PL-AC: Distance in $\mathrm{cm}$ from the posterior line to the acromioclavicular joint. PL-LS: Distance in $\mathrm{cm}$ from the posterior line to vertebra L3. PL-ASIS: Distance in $\mathrm{cm}$ from the posterior line to the anterior superior iliac spine. PL-ATT: Distance in $\mathrm{cm}$ from the posterior line to the anterior tibial tuberosity. ASIS-G: Distance in $\mathrm{m}$ from the anterior superior iliac spine to the ground. PSIS-G: Distance in $m$ from the posterior superior iliac spine to the ground. AC-G: Distance in $m$ from the acromioclavicular joint to the ground. IAS-G: Distance in $m$ from the inferior angle of the scapula to the ground. Comparing the PB angles obtained from $\mathrm{SAPO}^{\circ}$ in the sagittal plane, we found the right side (12.7 \pm 4.2 degrees) and the left side $(12.5 \pm 3.7$ degrees $)$ to be statistically similar ( $p=0.786)$.

In the comparative analysis of the average angles in the sagittal plane using time of practice as the separation variable, there was no difference in axial alignment between the groups (Table 2). In terms of the postural misalignments observed in the anterior and posterior views of the frontal plane, the results were similar, demonstrating that there were no significant differences between the groups in terms of time practicing ballet (Table 2).

Using height and BMl as separation variables, we verified that there was no association between them and the postural misalignments evaluated in the frontal plane (Table 3).

\section{DISCUSSION}

This study quantitatively evaluated the static posture of classical ballerinas, based on the premise that the practice of ballet imposes the execution of extreme articular movements and that these impositions can encourage changes in the postural alignment of the dancers. ${ }^{7}$

Table 1. Comparative analysis of the average distances between the anatomical references by laterality in ballerinas. Petrolina, PE, Brazil, $2015(n=19)$.

\begin{tabular}{|c|c|c|c|}
\hline \multirow{2}{*}{ Averages } & \multicolumn{2}{|c|}{ Laterality } & \multirow{2}{*}{ p-value } \\
\hline & Right & Left & \\
\hline \multicolumn{4}{|c|}{ Frontal plane - Anterior view } \\
\hline TMJ-AC, cm & $19.0 \pm 1.8$ & $19.3 \pm 2.3$ & 0.401 \\
\hline TMJ-G, m & $1.59 \pm 0.08$ & $1.60 \pm 0.08$ & 0.001 \\
\hline AC-G, m & $1.42 \pm 0.07$ & $1.43 \pm 0.07$ & $<0.001$ \\
\hline ASIS-AC, cm & $43.8 \pm 2.8$ & $44.1 \pm 2.8$ & 0.432 \\
\hline ASIS-G, m & $0.98 \pm 0.05$ & $0.99 \pm 0.05$ & $<0.001$ \\
\hline HF-G, m & $0.47 \pm 0.02$ & $0.47 \pm 0.02$ & 0.017 \\
\hline \multicolumn{4}{|c|}{ Sagittal plane - Profile view } \\
\hline PL-TMJ, cm & $14.2 \pm 1.6$ & $18.6 \pm 2.1$ & $<0.001$ \\
\hline$P L-C S, c m$ & $6.3 \pm 1.3$ & $10.3 \pm 1.7$ & $<0.001$ \\
\hline$P L-A C, c m$ & $12.5 \pm 2.3$ & $15.3 \pm 1.9$ & $<0.001$ \\
\hline$P L-L S, c m$ & $5.7 \pm 1.1$ & $7.5 \pm 1.6$ & $<0.001$ \\
\hline$P L-A S I S, c m$ & $22.3 \pm 2.2$ & $23.5 \pm 2.2$ & 0.007 \\
\hline $\mathrm{PL}$ - ATT, cm & $17.2 \pm 2.5$ & $14.7 \pm 1.7$ & $<0.001$ \\
\hline $\mathrm{PL}-\mathrm{HF}, \mathrm{cm}$ & $10.9 \pm 2.0$ & $8.2 \pm 1.7$ & $<0.001$ \\
\hline ASIS-G, m & $0.96 \pm 0.05$ & $0.95 \pm 0.05$ & 0.707 \\
\hline PSIS-G, m & $0.99 \pm 0.05$ & $1.00 \pm 0.05$ & 0.042 \\
\hline \multicolumn{4}{|c|}{ Frontal plane -Posterior view } \\
\hline PSIS-G, m & $0.97 \pm 0.05$ & $0.97 \pm 0.05$ & 0.056 \\
\hline AC-G, m & $1.33 \pm 0.09$ & $1.33 \pm 0.09$ & 0.778 \\
\hline IAS-G, m & $1.25 \pm 0.10$ & $1.24 \pm 0.09$ & 0.327 \\
\hline
\end{tabular}


Table 2. Comparative analyses by time practicing ballet, angular measurements taken in the sagittal plane obtained from $\mathrm{SAPO}^{\circ}$, and postural misalignments in the anterior and posterior views collected by FISIOMETER ${ }^{\circledR}$ software $(n=19)$.

\begin{tabular}{|c|c|c|c|c|c|}
\hline \multirow{5}{*}{$\begin{array}{l}\text { Measurements in the sagittal } \\
\text { plane }\end{array}$} & \multirow{3}{*}{ Postural paternal } & Sample & \multicolumn{2}{|c|}{ Time of practice } & \multirow{3}{*}{$\mathrm{p}$-value } \\
\hline & & \multirow{2}{*}{$\begin{array}{c}\mathrm{n}=19 \\
\text { Mean } \pm \mathrm{SD}\end{array}$} & \multirow{2}{*}{$\begin{array}{c}\leq 10 \text { years } \\
n=11\end{array}$} & \multirow{2}{*}{$\begin{array}{c}>10 \text { years } \\
n=8\end{array}$} & \\
\hline & & & & & \\
\hline & Cervical lordosis & $36.3 \pm 4.9$ & $37.3 \pm 4.4$ & $34.8 \pm 5.7$ & 0.292 \\
\hline & Thoracic kyphosis & $76.5 \pm 9.2$ & $76.4 \pm 10.0$ & $76.6 \pm 9.3$ & 0.965 \\
\hline \multirow{8}{*}{$\begin{array}{l}\text { Postural misalignments in } \\
\text { anterior and posterior views }\end{array}$} & \multirow{2}{*}{\multicolumn{2}{|c|}{ Variables }} & $\leq 10$ years & $>10$ years & \multirow[t]{2}{*}{ p-value } \\
\hline & & & $n=11$ & $\mathbf{n}=\mathbf{8}$ & \\
\hline & \multicolumn{2}{|c|}{ Misalignment in the anterior view } & & & \\
\hline & \multicolumn{2}{|c|}{ Head in relation to the shoulder girdle. $n(\%)$} & $4(36.4)$ & $3(37.5)$ & 1.000 \\
\hline & \multicolumn{2}{|c|}{ Pelvis in relation to the ground. $\mathrm{n}(\%)$} & $4(36.4)$ & $3(37.5)$ & 1.000 \\
\hline & \multicolumn{4}{|c|}{ Misalignment in the posterior view } & \\
\hline & \multicolumn{2}{|c|}{ Pelvis in relation to the ground. $\mathrm{n}(\%)$} & $1(9.1)$ & $0(0.0)$ & 1.000 \\
\hline & \multicolumn{2}{|c|}{ Shoulder girdle in relation to the ground. $\mathrm{n}(\%)$} & $3(27.3)$ & $2(25.0)$ & 1.000 \\
\hline
\end{tabular}

Table 3. Association between postural misalignment of the classical ballerinas in the frontal plane by height and BMI obtained using FISIOMETER ${ }^{\circledR}$ software $(n=19)$

\begin{tabular}{|c|c|c|c|c|c|c|}
\hline \multirow[b]{2}{*}{ Variables $\mathrm{n}(\%)$} & \multicolumn{3}{|c|}{ Height } & \multicolumn{3}{|c|}{ BMI } \\
\hline & $\begin{array}{c}<160 \mathrm{~cm} \\
\mathrm{n}=10\end{array}$ & $\begin{array}{c}\geq 160 \mathrm{~cm} \\
n=9\end{array}$ & p-valor & $\begin{array}{c}<21.75 \mathrm{~kg} / \mathrm{m} 2 \\
\mathrm{n}=10\end{array}$ & $\begin{array}{c}\geq 21.75 \mathrm{~kg} / \mathrm{m} 2 \\
n=9\end{array}$ & p-value \\
\hline \multicolumn{7}{|l|}{ Misalignment according to the anterior view } \\
\hline Head in relation to the ground & $1(10.0)$ & $2(22.2)$ & 0.582 & $2(20.0)$ & $1(11.1)$ & 1.000 \\
\hline Shoulder girdle in relation to the ground & $3(30.0)$ & $5(55.6)$ & 0.370 & $5(50.0)$ & $3(33.3)$ & 0.650 \\
\hline Pelvis in relation to the ground & $3(30.0)$ & $4(44.4)$ & 0.650 & $3(30.0)$ & $4(44.4)$ & 0.650 \\
\hline \multicolumn{7}{|l|}{ Misalignment according to the posterior view } \\
\hline Pelvis in relation to the ground & $1(10.0)$ & $0(0.0)$ & 1.000 & $1(10.0)$ & $0(0.0)$ & 1.000 \\
\hline Shoulder girdle in relation to the ground & $3(30.0)$ & $2(22.2)$ & 1.000 & $4(40.0)$ & $1(11.1)$ & 0.303 \\
\hline
\end{tabular}

In general, the specific postural pattern of the sample evaluated here was inclination of the head and the pelvis to the right and elevation of the left shoulder in the frontal plane, rotation of the trunk to the right in the axial plane, and protrusion of the head, rectification of cervical lordosis, increase in thoracic kyphosis, increase in lumbar Iordosis, pelvic anteversion, and hyperextension of the knees in the sagittal plane. However, it is important to note that despite the full use of photogrammetry in the postural analysis of ballerinas, the studies $^{9-12}$ diverge in terms of the parameters used, creating difficulties in analyzing and contextualizing the results.

The postural deviations in the frontal plane tend to be compensated in order to maintain verticality. ${ }^{21}$ The trunk is the region of all static compensations, thus, an imbalance in the cervico-cephalic region causes a bad scapular position, which is compensated in the area of the truck by a descending deformation. ${ }^{22}$

In this sense, the inclination of the head to the right and the elevation of the shoulder to the left, confirmed in the ballerinas in this study, probably reflect a compensatory pattern of the myoaponeurotic system, with a predominance of unilateral actions of the prevertebral muscles, such as the sternocleidomastoid (SCM) along the neck and the head, the deep postvertebrals such as the suboccipitals, and the superficial postvertebrals such as the splenius, upper trapezius, and levator scapulae..$^{23}$

The mediolateral stability of the pelvis is established through the tonic synergy of the hip abductor and adductor muscles. ${ }^{24}$ Imbalance between these groups can cause pelvic tilt. The intensive long-term practice of ballet routines affects the articular kinematics of the pelvis and lower limbs, ${ }^{7}$ especially one leg en pointe support. The pelvic tilt in the frontal plane observed in the ballerinas evaluated in this study corroborates the findings of a study of 13 professional ballerinas in the Czech Republic, and probably results from the maximum extension and the abduction of the hip during dance movements. ${ }^{7}$

The analysis of the distances from the anatomical markers to the $\mathrm{PL}$ in the sagittal plane suggests a pattern of rotation of the head and shoulder girdle to the right. These findings can be the result of repetitive executions of performance turns, linked to the ballerina's preference to perform them with the dominant side. ${ }^{9}$ This continuous process can promote greater muscular activity of the prevertebrals 
and suboccipitals, which in unilateral actions can promote the rotation of the head and the cervical spine, as well as the psoas and the external oblique, which in contralateral actions, in synergy with the internal homolateral oblique, promote rotation of the trunk. ${ }^{23}$

In this study, the measurement of angles in the sagittal plane followed the method proposed by a study that compared women who used high heels continuously (group G1) and sporadically (group G2). ${ }^{17}$ The authors determined that the lower the value of the $\mathrm{PH}$, the greater the protrusion of the head and the greater the value of the $\mathrm{CL}$, the greater the cervical rectification. The study found average values equal to $53.11^{\circ}$ and $32.45^{\circ}$, respectively, for the $\mathrm{PH}$ and $\mathrm{CL}$ angles measurements in group G1. A comparison with the findings allows us to infer that the dancers evaluated here had more protruding heads and more rectified cervical lordosis than the women in G1

The pattern of protrusion of the head and cervical rectification indicated greater bilateral activity of the suboccipital muscles in synergism with the prevertebrals responsible for the extension of the head and cervical rectification. ${ }^{23}$ This postural behavior probably results from the tonic hypersolicitation of this musculature in maintaining the head erect while performing dance. In line with these findings, a study conducted in Salvador-BA observed protrusion of the head in all of the ballerinas evaluated $(n=14){ }^{9}$

The evaluation of thoracic kyphosis obtained from the TK angle assumed that the greater the angle, the greater the rectification of the curvature. ${ }^{17}$ The sample analyzed in this study had an average lower value than that described in the study used as a parameter $\left(\mathrm{TK}=84.88^{\circ}\right)$, allowing us to deduce that the ballerinas in this study had increased thoracic kyphosis. This pattern is mentioned in the literature as a physiological compensatory mechanism for cervicocephalic imbalances, since the tonic muscles of this region, of the spinal transverse for example, control the static acting bilaterally. ${ }^{25}$

Pelvic position is the key determinant of lumbar sagittal balance, i.e., when pelvic anteversion occurs, the lumbar spine will be in a lordotic pattern. ${ }^{22}$ This kinesiological relationship was observed in this study, because the average PB angle had a similar value and the $\mathrm{LL}$ angles had a greater value than those reported in the parametric study ${ }^{17}\left(P B=12.6^{\circ}\right.$ and $L L=57.6^{\circ}$, respectively). This misalignment probably derives from the postural adjustments necessary to perform a turnout, ${ }^{11,12}$ as well as from the sustained contraction of the muscles posterior and lateral to the trunk, for example the latisssimus dorsi and quadratus lumborum, ${ }^{23}$ that act bilaterally during the execution of jumps with hyperextension of the spine. ${ }^{22}$ We stress that this pattern is described as a characteristic of postural adjustment in beginner ballerinas, ${ }^{26}$ diverging from the sample studied here that has a time of practice greater than 10 years.

In terms of posture, the expected pattern in professional classical ballerinas is of neutrality or pelvic retroversion with rectification of the vertebral curves. This pattern is justified by a reduction of the forefoot support base and the use of pointe shoes for more than six years, the main adjustment from which is being pelvic retroversion associated with a reduction of the angle of $L L .9,17$

In this study, the anthropometric data and the time of practice apparently did not interfere with the postural pattern adopted by the sample, suggesting that the misalignments found resulted from compensatory adjustments made in executing specific ballet positions.

Being aware of the postural tendencies of classical ballerinas is important in the sense that it sends a message to the population studied to establish measures to prevent erroneous postural patterns capable of causing pain and injuries. Muscular imbalances, variations in tonus, and continuous joint positioning can cause stress injuries and joint wear. Faced with these conditions, the indication for physiotherapeutic intervention aimed at postural reeducation is valid towards improving, developing, and maintaining the physical capacity of these professionals.

It is necessary, however, to mention the methodological limitations of this study, such as the sample size and the type of study, since transversal cuts temporarily restrict postural diagnosis, emphasizing the importance of conducting longitudinal studies on this theme. Additionally, our lack of knowledge about the weekly training routine and the time that pointe shoes were used limits our discussion of the findings of this study.

\section{CONCLUSION}

The results presented here allow us to conclude that the practice of classical ballet promoted changes in the alignment of the head, trunk, shoulder girdle, and pelvic girdle, as well as the vertebral curves of the ballerinas in our sample. However, the sample size limited the extrapolation of the results to the general population, Nonetheless, this study pointed out the need for physiotherapeutic intervention aimed at postural reeducation in order to contribute to the kineticfunctional balance of classical ballet dancers.

\section{ACKNOWLEDGEMENTS}

We would like to thank all the ballerinas for their participation in the study. We also thank the professors of the RIDE ballet schools of the Petrolina/PE and Juazeiro/BA pole, Prof. Andrezza Silva Azevedo, Prof. Carla Martins Peixinho, Prof. Flaviana Carla Vieira de Moura, Prof. Nazareth Macedo, and Prof. Vildete Martins Cezar de Cabral for their help in conducting the research.

All the authors declare that there are no potential conflicts of interest regarding this article.

CONTRIBUTIONS OF THE AUTHORS: Each author made significant individual contributions to the development of the manuscript. JNR and RCOA were the main contributors to the writing of the manuscript. JNR, UISM, and LRM conducted the evaluation, monitored the volunteers, and gathered the statistical analysis data. PAS and RCOA evaluated the statistical analysis data. BAA and RCOA performed the bibliographical research, the revision of the manuscript, and contributed to the intellectual concept of the study.

\section{REFERENCES}

1. Leanderson C, Leanderson J, Wykman A, Strender LE, Johansson SE, Sundquist K. Musculoskeletal injuries in young ballet dancers. Knee Surg Sports Traumatol Arthrosc. 2011;19(9):1531-5.

2. Faria F, Atalaia T, Carles M, Coutinho I. Knee angular displacement analysis in amateur ballet dancers: A pilot study. Eur J Physiother. 2013;15(4):215-20.

3. Prochazkova M, Tepla L, Svoboda Z, Janura M, Cieslarová M. Analysis of foot load during ballet dancers' gait. Acta Bioeng Biomech. 2014;16(2):41-5.

4. Martinez $B$, Curtolo M, Lucato $A$, Yi L. Balance control, hamstring flexibility and range of motion of the hip rotators in ballet dancers. Eur J Physiother. 2014:16(4):212-218.

5. Allen N, Nevill A, Brooks J, Koutedakis Y, Wyon M. Ballet injuries: injury incidence and severity over 1 year. J Orthop Sports Phys Ther. 2012;42(9):781-90
6. Aquino C, Cardoso V, Machado N, Franklin J, Augusto V. Análise da relação entre dor lombar e desequilíbrio de força muscular em bailarinas. Fisioter Mov. 2010;23(3):399-408.

7. Tepla L, Prochazkova M, Svoboda Z, Janura M. Kinematic analysis of the gait in professional ballet dancers. Acta Gymnica. 2014;44(2):85-91.

8. Norkin CC, Levangie PK. Postura. In: Norkin CC, Levangie PK. Articulações, estrutura e função: uma abordagem prática e abrangente. 2a. ed. Rio de Janeiro: Revinter; 2001. Cap. 13, p. 413-34.

9. Meira G, Gonçalves L, Baptista A Mendes S, Ribas S, Sá K. Perfil Postural de Bailarinas Clássicas: análise computadorizada. Rev Pesq Fisioter. 2011;1(1):19-28. 10. Fernandes S, Oelke J, Hartmann A, Kohler A, Gerhardt A, Marchi C. Alterações 
posturais no Ballet. Contexto Saude. 2011;10(20):643-6.

11. Prati $S$, Prati A. Níveis de aptidão física e análise de tendências posturais em bailarinas clássicas. Rev Bras Cineantropom Desempenho Hum 2006:8(1):80-7.

12. Meereis E, Favretto $C$, Bernardi C, Peroni A, Mota C. Análise de tendências posturais em praticantes de balé clássico. Rev Educ Fís UEM. 2011;22(1)27-35.

13. Keller K, Corbett J, Nichols D. Repetitive strain injury in computer keyboard users: pathomechanics and treatment principles in individual and group intervention. $J$ Hand Ther. 1998;11(1):9-26.

14. Venturelli W. Correlação das alterações posturais e da espirometria em crianças respiradoras bucais [dissertação]. Rio de janeiro, RJ: Universidade Federal do Rio de Janeiro; 2006.

15. Ferreira E. Postura e controle postural: desenvolvimento e aplicação de método quantitativo de avaliação postural [dissertação]. São Paulo, SP: Universidade de São Paulo; 2005.

16. Santos A. Diagnóstico clínico e postural: um guia prático. 4a. ed. São Paulo: Summus; 2001

17. Iunes D, Monte-Raso V Santos C, Castro F, Salgado H. A influência postural do salto alto em mulheres adultas: análise por biofotogrametria computadorizada.
Rev Bras Fisioter. 2008;12(6):441-6

18. Tirapegui J, Ribeiro S. Avaliação nutricional. Rio de Janeiro: Guanabara Koogan; 2009

19. Isosaki M Cardoso E Oliveira A Manual de dietoterapia e avaliação nutriciona do Serviço de Nutrição e Dietética do Instituto do Coração-HC-FMUSP. São Paulo: Atheneu; 2009.

20. World Health Organization. Obesity: preventing and managing the global epidemic Geneva: World Health Organization; 1998

21. Kendall F, McCreary E, Provance P, Abeloff D, Andrews P, Krausse $C$, et al. Músculos: provas e funções com Postura e dor. São Paulo: Editora Manole; 1995

22. Bienfait M. Os desequilíbrios estáticos: filosofia, patologia e tratamento fisioterápico. 4a. ed. São Paulo: Summus; 1995.

23. Kapandji A. Fisiologia articular. São Paulo: Medica Panameri; 2010

24. Pandy MG, Lin YC, Kim HJ. Muscle coordination of mediolateral balance in normal walking. J Biomech. 2010;43(11):2055-64.

25. Pereira ACMI, Silva VJS; Lima FCVM. Avaliação postural em bailarinas clássicas pelo método da biofotogrametria computadorizada. Ter Man. 2008;6(23):11-7.

26. Moller A, Masharawi Y. The effect of first ballet classes in the community on various postural parameters in young girls. Phys Ther Sport. 2011;12(4):188-93. 